Roman SZUL

University of Warsaw

r.szul@chello.pl

\title{
(IN)EQUALITY OF LANGUAGES IN THE EU AND ITS ECONOMIC AND POLITICAL CONSEQUENCES
}

ABSTRACT Language policy (both explicit and implicit) of the EU serves several objectives: to ensure the equality of EU member states and their citizens, to enable the smooth functioning of EU institutions, to improve the economic performance of the EU and to create a sense of community within the UE. These objectives are contradictory which leads to a choice between the idealistic principle of equality of languages and the pragmatic inequality of languages, which in turn generates tensions in the EU over the economic and political consequences of both the equality and inequality of languages. The principle that the EU is a free association of member states implies the equality of all 24 (after Croatia's accession) official EU languages. This discriminates against citizens whose mother tongues are different than those 24 languages, and, at the same time, generates problems related to the abundance of languages (organisation and costs of translation/interpretation). The smooth functioning of EU institutions, of the EU economy and market, requires the use of a reduced number of languages which is economically and politically disadvantageous for users of other languages and provokes conflicts as in the case of the unique European patent.

Key words: EU, language policy, official languages, working languages 


\section{INTRODUCTORY REMARKS}

One of the dimensions of the European Union, apart from economy, finances, voting systems in EU institutions, freedom of traveling etc., is its linguistic dimension. As in the case of the other dimensions it causes some problems with political and economic consequences. The source of these problems can be summarised as the unresolved question of equality vs. inequality of the languages of the EU. Although the language problem does not constitute a substantial challenge for the European Union, it still deserves attention, even more so because with the growing number of member states the number of official and non-official languages in the EU is also growing. It should be said that languages as such (their grammar, vocabulary, phonetics, etc.) do not cause serious problems. They can, however, lead to substantial difficulties when language problems are combined with or cause economic and political conflicts within the EU. In such a way the language issue can add to the general problems related to the functioning of the EU.

The aim of this paper is to analyse particular language problems and the language policy of the EU and their economic and political consequences. The analysis is focused on EU institutions, leaving behind the territory of the European Union with its member states and their language situations and policies. The aim of this paper is not to analyse the details of the language situation and policy of the EU. ${ }^{1}$ It should also be stressed that this paper does not analyse, apart from some short comments, the language policy of other European institution, most of all of the Council of Europe - an institution otherwise very active in the promotion of multilingualism, linguistic rights of national minorities and regional communities.

\section{LANGUAGE POLICY OF THE EUROPEAN UNION - BASIC ASSUMPTIONS}

Language policy in (the territory of) the European Union is a multi-level policy. It entails two or three levels: the EU level (or language policy of the European Union), the national level (language policies of individual member states) and, in some cases, the regional level (language policies of sub-national territorial units). According to the principle of subsidiarity each level is independent and responsible for its sector of activity. Consequently, the EU level regulates the language situation (use of individual lan-

Polish and international readers can find such analyses in e.g. J. Łuczak, Polityka jezzykowa Unii Europejskiej, Warszawa 2010; L. Marácz, 'Multilingualism in Europe: Policy and Practice Introduction to Part I', European Studies, No. 29 (2012), pp. 21-35; R Szul, 'Tożsamość europejska a kwestia językowa w Unii Europejskiej', Studia Regionalne i Lokalne, No. 4 (2007), pp. 66-76; idem, 'The Linguistic Situation in Europe: between Regionalism and European Integration', The Polish Foreign Affairs Digest, Vol. 4, No. 1 (2004), pp. 127-168; C. Truchot, Europe. L'enjeu linguistique, Paris 2008 (Etudes de la Documentation Française, 5280). 
guages) in institutions of the EU, including the contacts of these institutions with $\mathrm{EU}$ citizens and organisations. The national level consists of policies of individual member states which are free to regulate all issues related to culture, nationality (citizenship) etc., including the language policy on their territories. In some sub-national units (e.g. in Spanish regions of Catalonia, the Basque Country, Galicia, the Balearic Islands and Valencia, in Wales in the UK, in the autonomous regions and provinces of Italy, etc.) regional and local governments, in the framework of national regulations, may carry out a language policy different from that on the national level. In an ideal situation the EU and the national (and regional) level should be separated: the EU should not interfere in the language policy of individual states, and the states should not dictate (otherwise than in accordance with accepted rules) the language practices of EU institutions. In practice, however, sometimes there are contradictions (conflicts) between levels of language policy, or between individual states, with the EU level being asked to intervene. Such interventions can also be considered an element of the EU's language policy.

The language policy of the EU is meant to fulfill four aims:

- to ensure the equality of EU member states and of their citizens,

- to enable the smooth functioning of EU institutions,

- to improve the efficiency of the EU economy,

- to create a sense of community within the UE.

As can be seen from the following discussion, these aims are to some extent contradictory It should be mentioned that the above aims are a kind of conclusion drawn from observation of practices in the EU rather than a set of principles enshrined in official documents. In other words, the EU's language policy is rather an implicit policy resulting from, sometimes diverging, interpretations of existing principles and regulations.

\section{EQUALITY OF EU MEMBER STATES, CITIZENS AND LANGUAGES}

The first aim stems directly from the nature of the European Union as a free association of sovereign (equal) nation states formed by free and equal citizens. In theory this means that the number of official languages in the European Union ought to be equal to the number of all the official national languages of existing member states. This assumption arises from the $19^{\text {th }}$ century notion of nation state according to which each nation state has a national (state) language (in line with the idea of "one state - one nation - one language"), the proficient usage of which by all citizens is a prerequisite of their equality vis-à-vis the state and of practicing their civil rights. In other words, each citizen is expected to know and use the national language, knowing and using other languages is considered at best as superfluous and his/her own private issue (not his/ her right warranted by the state), at worst as dangerous for national unity. In such a case a "perfect" nation state has only one language and all the population speak it. Consequently, the European Union, as a free association of nation states, is a collection of the national languages of its member states. Before the recent (1 July 2013) accession of 
Croatia the number of member states of the EU was 27 and the number of official EU languages was 23. (Four member states - Austria, Luxemburg, Belgium and Cyprus have brought no new languages into the EU as their national official languages - German, French, Dutch and Greek - are national languages of other member states). After Croatia's accession these numbers have grown respectively to 28 (member states) and 24 (official languages). These languages are: Bulgarian, Croatian, Czech, Dutch, Danish, English, Estonian, French, Finnish, German, Greek, Hungarian, Irish, Italian, Latvian, Lithuanian, Maltese, Polish, Portuguese, Romanian, Slovak, Slovene, Spanish and Swedish. The inclusion of a member state's national language into the list of official EU languages is automatic and is not a subject of negotiation or verification if this language really fulfils the role of official national language.

It should be added that in practice not all of these 23 languages (before Croatia's accession) fulfill all the functions of official EU languages. Irish is in a special situation. Irish is nominally (according to the Irish constitution) the national and official language of the Republic of Ireland and as such it could have gained the status of official language of the EU (or its predecessor the European Economic Community - EEC) from the very beginning of Irish membership of the EEC. However, given the fact that in practice it does not play the role of fully-fledged official language of Ireland, this role being fulfilled by English, and because practically the whole population of Ireland knows English perfectly, Ireland, when joining the EEC, did not demand making Irish a regular official language of the EEC. It had a special status of non-official language of the EEC/EU. The situation changed in 2004 when Malta joined the EU. The language situation of Malta is largely similar to that of Ireland with a wide-spread use and knowledge of English and limited functions of the local national language - Maltese (although in everyday life Maltese is much more commonplace than Irish in the Republic of Ireland). Malta did not hesitate to request the status of official EU language for Maltese, although for practical reasons (lack of qualified translators/interpreters in sufficient numbers) its functioning as a regular EU official language was postponed. Nevertheless, the case of Maltese encouraged the Irish to demand the same status for Irish. Irish received this status in 2007. Upgrading Irish to the status of official EU language has a mostly, if not exclusively, symbolic meaning - it satisfies the symbolic, identity needs of the Irish without alleviating their communication with the European Union.

The principle of equality of languages in practice means that politicians representing member states (participants of meetings of the Council of the European Union and of the European Council) and representing citizens (Members of European Parliament - MEPs) can use their national languages during the official meetings of these institutions, and receive translation (interpretation) from other languages into their languages. Also, citizens may address the EU institutions in any of the official languages and receive an answer in the same language.

Treating all of these 23 (24) languages as truly equal creates serious practical problems. In reality, it would mean that all documents produced by EU institutions should be published at the same time in all 23 (24) linguistic versions and, most importantly, all speeches in meetings of the European Parliament or other institutions, should 
be simultaneously and immediately translated into all the other languages (preferably by native speakers of those languages) which would result in the number of necessary translators (interpreters) reaching $23 \times 22=506$ (or $24 \times 23=552$ after Croatia's accession). Consequently, the meetings of 28 state leaders would be accompanied by 552 interpreters.

It should be underlined that even a strict implementation of the principle of equality of the EU's official languages does not guarantee equality of languages and citizens of the EU, let alone equality of inhabitants of the EU. Outside the list of the official languages of the EU are languages spoken by EU citizens and inhabitants which are not recognized as official EU languages, including languages used by millions of EU citizens and inhabitants, such as Catalan, Russian or Turkish, outnumbering users of many official EU languages.

Catalan has the status of co-official language (together with Spanish/Castilian) of two Spanish regions - Catalonia and the Balearic Islands, and, as Valencian (the difference between Catalan and Valencian is minor) also in the region of Valencia (Comunidad Valenciana). The number of speakers of Catalan definitely exceeds 5 million and is higher than the number of speakers of such official EU languages as Irish, Maltese, Danish, Finnish, Estonian, Latvian, Lithuanian, Slovene and equal, if not higher, than the number of speakers of Slovak and Croatian. Gaining an official status for Catalan in the $\mathrm{EU}$ is one of aims of the Catalan regionalist/nationalist movement. Apart from the sporadic use of Catalan in the Committee of the Regions, the efforts of promoters of Catalan in the EU have failed. The difference in the status of Catalan and the aforementioned small languages is the best illustration of the principle that the EU is an organisation of nation states and not of regions or any other subject. When analysing the case of Catalan, it can be added that this language, together with several others like Basque, Galician, Welsh, Frisian etc., is recognised as a "regional" language and protected by various documents adopted by the Council of Europe (first of all by the European Charter for Regional or Minority Languages). The status of Turkish in the territory of the EU is even worse than the status of Catalan - it is not recognised as a regional or minority language (outside a small area of eastern Greece) and not protected by any European convention. (Turkish is regarded as a language of immigrants, and, according to these conventions, immigrants have no linguistic rights).

\section{SMOOTH FUNCTIONING OF EU INSTITUTIONS}

To solve or soften the practical (technical) problems resulting from the multitude of languages some measures reducing the need for translation and interpretation have been implemented. The main measure is excluding EU functionaries from the automatic right to use their languages when working in EU institutions and, consequently, reducing the number of languages (called working languages) in these institutions to just a few. Another measure is the division of documents produced by the EU into official (that should be published in all official languages, all having legal validity) and 
unofficial that can be published only in selected working languages. Yet another measure is the technique of oral (simultaneous) translation using the so called relay system (speeches are translated into some basic or "platform" languages, and then from them into other languages). Both measures divide languages, and their users, into "better" and "worse". Besides, as mentioned earlier, some languages, such as Irish and Maltese, are not used as official languages in practice, or used to a very reduced degree.

Another measure reducing the need for translation, whose legality may be considered dubious, is the practice of EU bureaucracy using only its working languages, mostly English, in contacts with e.g. local authorities or other potential users of EU funds. This means that these authorities and organisations must submit documents in English and not in any other official EU language. The EU bureaucracy also has a tendency to extend this practice to contacts with member states. As can be seen below, this practice sometimes encounters opposition.

What is of special importance is that the division into "official" and "working" languages, "official" and "unofficial" documents and into "basic" and "other" languages is not based on any strict, agreed and accepted criteria. Rather, it is a matter of political influence of individual states, the number of speakers of individual languages, inertia or the tradition of language practice in the EU and the needs of the UE bureaucracy. For instance, the role of English results from its importance as a "natural" international language, but the still strong position of French is to some extent a result of the political influence of France which is used by the country to take care of the position of its language (for instance, France demands that the chairman of the European Commission speak French, otherwise France would veto a candidate who could not speak French). One of the immediate results of these measures is the inequality of languages and of their users in the EU, leading to, among other things, unequal chances to promote in the EU and reducing the number of potential candidates for the position of the chairman of the EC to persons knowing at least English (practical requirement) and French (political requirements of France). The inequality of languages expresses itself in several ways: in publishing or not-publishing of documents in individual languages, in the quality and time of receiving oral translation (interpretation) - users of "basic" or "platform" languages receive translation first and this translation is of better quality in the relay system of translation, in comparison to translations of translations. Apart from the technical or practical consequences of the inequality of languages, there are psychological and political consequences - the feeling of superiority or inferiority of people. It should be stressed that the formal equality of official languages (guaranteed by translation and interpretation) relates only to official meetings of politicians. Outside conference rooms they usually must cope without translation (interpretation) and must use international lingua francas which privilege their native speakers.

The main area where differences in the importance of languages are the most visible is, however, the use of working languages in the EU. The main working language of the EU bureaucracy is English, followed by French and German. Most documents are published only in these languages, sometimes also in languages of countries to which a specific document relates. Even though documents are published in several languages, 
the sequence of publication is uneven: some language versions appear first which gives some advantages to their users. This practical approach, despite reducing the number of languages and making the functioning of the EU more smooth, contradicts the idea of equality of languages, citizens and member states.

Practical inequality of languages may cause suspicion of manipulation at the expense of some categories (nationalities) of UE citizens. Just to mention two such cases: During the first years after new member states from Central-Eastern Europe joined the $\mathrm{EU}$, candidates from these countries applying for jobs in EU institutions had to pass all exams in foreign languages while their colleagues-competitors from the "old" member states could pass some exams in their national languages. This practice caused dissatisfaction, especially among Polish candidates who in 2007 complained against it to the EU ombudsman, who subsequently admitted that this practice violated the principle of equality of candidates and appealed for its cancellation. As a result, the institution responsible for recruiting employees to EU institutions (EPSO, European Personnel Selection Office) changed its rules of recruitment, eliminating linguistic discrimination against candidates from the new member states. ${ }^{2}$ It should be noted that the complaint by Polish candidates on behalf of candidates from the new members states came in an atmosphere of suspicion that the old member states (or precisely functionaries from these countries) used unfair methods to limit the position and incomes of employees from the new central-eastern European member states. Shortly before these countries joint the EU and their citizens started to work in its institutions, the EU bureaucracy changed its salary system so that it reduced the salaries of new employees and increased the salaries of functionaries with long careers in the EU. Given that employees form central-eastern European countries were almost exclusively new employees and functionaries with long careers in the EU were almost exclusively from the old member state, such a change in the salary system was interpreted as a hidden way of discrimination against citizens from the new members states. In such a situation, the unequal treatment of languages of candidates was considered as another trick to discriminate against the newcomers in the EU. Of course, the above-mentioned ruling of the EU ombudsmen related to the candidates' exams did not eliminate inequality of native speakers of the main working languages (especially English and French) and others as employees of EU institutions.

Another example of unequal treatment of languages causing suspicion of manipulation with political and economic consequences is the 2012 and early 2013 public consultation carried out by the European Commission (by its commissions dealing with

Before this change candidates from the "old" member states had to present their linguistic competences in one of the 11 languages of the "old" member states, including their native languages, while candidates from the "new" member states had to present their knowledge of one of those 11 languages, all of them being foreign languages. Besides, candidates from the "old" states could write a part of the exam in their native languages while candidates from the "new" member states had to pass this exam in one of three foreign languages - English, French or German. It is believed that this discrimination is one of the reasons for the relatively low presence of Polish citizens in EU administration. See: K. Niklewicz, 'Nasi wygrywają z biurokracją Unii Europejskiej', Gazeta Wyborcza, 22 May 2007, p. 10. 
energy and ecology) on shale gas exploitation. Apart from the formulation of the questionnaire suggesting that the EC was against the exploitation of shale gas, the internet questionnaire was first published only in English, French and German. According to Polish media and Polish MEPs this put Poland, a big enthusiast of shale gas (for political and economic reasons), in a disadvantageous position. Only after protests of Polish MEPs were the questionnaires in Polish and other languages made available for the public. ${ }^{3}$ This, again, took place in the atmosphere that the EC was not neutral in the consultation and was playing an unfair game against proponents of exploitation of shale gas and the unequal use of languages was another trick to push its opinion through. The spokesman of the EC commission of ecology rejected this accusation and as evidence of the neutrality and fairness of the EC in the public consultation on shale gas he quoted the fact that although such consultations are usually carried out only in English, French and German, the consultation on shale gas was finally carried out in all the official languages. This statement deserves comment. Carrying out public consultations only in some languages is contradictory to the principle that EU citizens can address the EU in any of its official languages (and receive answers in this language). It confirms the practice that the EU bureaucracy treats its partners as its functionaries addressing them only in the main EU working languages.

It should be stressed that speakers of practically all languages but English are dissatisfied with the position of their languages in the EU. The French, whose language is now the second most important language in the EU, are frustrated because their language has lost its leading position and is still losing distance to English. ${ }^{4}$ (Some) Germans complain that their language, which has the highest number of native speakers, does not enjoy a proportional position in the EU. For similar reasons, the Italians and the Spaniards are also seriously dissatisfied.

\section{IMPROVING EFFICIENCY OF THE EU ECONOMY}

There are several ways in which the EU tries to enhance its efficiency by using language policy. Until a few years ago the principle of efficiency in language policy was related only to the free movement of people (including the labour force), goods and capital

3 See for details J. Żylińska, 'KE broni konsultacji publicznych ws. gazu łupkowego', Gazeta Wyborcza, 19 April 2013.

4 On the fall of French and the rise of English in the EU see e.g. C. Truchot, Europe..., pp. 75-96. He points out that while in 1986 the majority of primary texts of the European Commission were still written in French (58\%), with English occupying the second position (26\% of texts), in 2007 12,3\% of primary texts were written in French and $73,5 \%$ in English $(2,4$ in German and 11,8\% in other languages). (Ibid., p. 83)

5 When the European Commission in 2006 sent a document to the German parliament in English asking for the opinion of the parliament on an issue (readiness of Romania to join the EU), the chairman of the German parliament Norbert Lammert protested and warned that the parliament would ignore EU documents in other languages than German - N. Lammert, 'Apokalyptische Erfahrungen', Der Spiegel, 2 October 2006. 
within EU borders (the common market). The purpose of the language policies resulting from this principle was, first of all, to facilitate these movements byemploying various forms of support in the learning of foreign (European) languages in order to overcome language barriers, and secondly, to eliminate unnecessary (unjustified) language barriers (language requirements) imposed by national (or regional) authorities. As can be seen, the latter directly intervenes in the realm of national language policy.

As to language learning, the policy at the EU level consisted in the promotion of the idea of "multilingual Europe of plurilingual Europeans" speaking at least three languages (one's own national language plus two foreign languages: one language of a neighbouring country and one international language). This policy was mainly pursued by student exchange programmes financed by the EU, and by various "sensitivity actions" aimed at convincing the public opinion of the benefits of multilingualism (among such actions one can mention the Year of Languages 2001 announced by the European Union and the Council of Europe). This policy did not cause serious problems, except for some complains that in practice it favoured English - the most widely used foreign language, the language used by students participating in EU-supported international student exchange programmes, etc.

A more problematic issue is the policy of not imposing unnecessary linguistic requirements for those who want to be employed or to move to another country. As regards employment, it is obvious that some degree of command of the language (a concrete language) is necessary to fulfil the obligations resulting from a given form of employment. The problem surfaces when a country wants to use language requirements just to stop foreigners from migrating to the country and taking jobs. In some countries, like the Netherlands, Germany and Austria, using language policy to stop immigration became a widespread phenomenon in recent years (especially after 2001). In some cases foreigners had to pass language exams to enter the country, and those already in it were obliged to learn the local language. This policy, however, was addressed only to non-EU citizens. The rise of anti-immigration sentiments in some countries, chiefly in the Netherlands, resulted in the Dutch government trying to implement the same approach towards immigrants from other EU countries, including Poles ${ }^{6}$ among others, which contradicts the principle of free movement of people in the EU. This caused dissatisfaction within the Polish government which warned that it would raise this issue in the European Union.

In recent years, the attempt to use language policy to increase the competitiveness of the EU economy has acquired a new dimension and triggered a serious conflict. This phenomenon is the idea of the European patent. ${ }^{7}$ To explain the question of the European patent in a simple way, it can be said that until this idea was launched, inventors

See P. Maciejewicz, 'Holandia chce Polaków do pracy. Ale bez zobowiązań', Gazeta Wyborcza, 31 December 2010.

For more details see 'The EU's Unitary Patent: Yes, Ja, Oui, No, No', The Economist, 13 December 2012; “'Un brevet unique permettra à l'Union européenne d'être plus compétitive”. Entretien avec le professeur Alain Pompidou', Entretien d'Europe, No. 55 (2011), at <http://www.robert-schuman.eu/ entretien_europe.php?num=55>; A. Łada, 'Patent na Prezydencję?', Gazeta Wyborcza 8 March 2011. 
who wanted to patent their inventions in the EU, had to patent their inventions separately in each country and prepare (translate) documents in all the official languages of these countries. This made patenting in the EU several times more expensive than in the USA or Japan, the main competitors to the EU. Even patenting in the biggest $\mathrm{EU}$ countries is very expensive. To reduce costs of patenting in the EU, the idea of the unique European patent was launched. In its original version there should be just one language of patenting - English. In consequence, France and Germany began to protest and demanded the inclusion of their languages as languages of the European patent. Obviously, these protests were motivated by political (prestigious) and economic considerations. As a result of political disputes, French and German were finally added to the list of languages of the European patent. This, in turn, encouraged Spain and Italy to also demand the inclusion of their languages, arguing that their languages were not worse than German or French. This demand, if satisfied, would increase the number of patent languages to five, thus largely offsetting the effects of the idea of the European patent. During the following discussion Spain and Italy did not give up their demands and the remaining countries rejected them. Given that such a decision in the Council should be made unanimously, the situation caused a political impasse. The impasse was solved in such a way that all countries but Spain and Italy recognized an "enhanced cooperation" agreement on the European patent (with the three above-mentioned languages). This "pushing out" of Spain and Italy from the European patent agreement raises doubt about its legality and political purposefulness. Besides, pushing such big countries (the fourth and fifth economy in the EU) out of the European patent system reduces its rationality.

The intergovernmental agreement on the European patent (not yet ratified by all member states), while taking into account the needs of inventors - patent holders, in practice big firms from the richest countries - fails to satisfy the demands of potential patent users form less developed countries. Previously they had access to patent documentations in their languages. If the European patent is ratified they will only have access to patents in foreign languages which would force them either to bear the costs of translation, not only to decide to buy or not to buy the patent, but also to avoid the unintentional breaching of patent rights when introducing their own innovations, or, to avoid the costs by not translating the documentation and thus risking the breaching of patent rights and being sued (or blackmailed) by powerful foreign firms (or by the so called "patent trolls") claiming rights to these innovations. In any case it would mean additional costs. This is why Polish firms and the business community are mostly against the European patent and try to persuade the government not to ratify it. ${ }^{8}$ The Polish government, according to recent information (March 2013) shares this opinion. ${ }^{9}$

'Eksperci przeciwko jednolitemu patentowi europejskiemu', Gazeta Wyborcza, 14 February 2013.

'Piechociński nie zwróci się do rządu o przyjęcie jednolitego patentu', Gazeta Wyborcza, 20 March 2013. 


\section{SENSE OF COMMUNITY}

The sense of community in the European Union, as in any other community, requires 1) common language(s) as means of communication, and 2) emotional identification with the EU as a community and with its language(s).

The first requirement implies the existence of common language(s) or lingua franca serving as means of communication and transmitting information and ideas necessary to create a sense of community. In the present situation the common languages of the EU are in practice the above-mentioned English followed by French and German. Promotion by EU institutions of the sense of unity, e.g. via student exchanges, as mentioned earlier, in fact promotes first of all English. It should be mentioned that common languages play a double role of integrating and disintegrating Europeans: common languages divide inhabitants of the EU into three categories 1. native speakers of the common language (s), 2. non-native speakers, 3. non-speakers. Consequently, while common languages integrate some sectors of the population across national borders, they also alienate those who do not speak these languages (or do not speak them fluently enough to feel comfortable and make use of opportunities resulting from using them). Paradoxically, the language best suited to the role of European lingua franca is the native language of the nation least inclined to the idea of the $\mathrm{EU}$ as a community, i.e. the UK.

The second requirement means that a community needs a language as its symbol of unity and identity (regardless of its use as means of communication) and evoking positive emotions. In practice, the European Union lacks such a language. EU citizens identify themselves primarily or exclusively with their national languages (sometimes also with regional languages) and not with European lingua francas. English, as the main common language in Europe, can not play the symbolic role of European language, among other things due to the fact that it is also the global lingua franca, and, as such, does not separate Europe from the rest of the world. An additional argument against English as symbolic language of the European Union is that one of the original aims of European integration, especially as understood by France, was to counterweigh the political, economic and cultural influence of the Anglo-Saxons. ${ }^{10}$ Some people try to make British English, as opposed to American English, a symbolic and practical European language (for instance, UE institutions use almost exclusively British English), but it is doubtful that British English, as any other language or variety, can really become the symbolic and emotionally-binding language of Europeans.

Given the impossibility of fostering the sense of European unity by promoting one common language (or a few languages) as emotional symbols of identity and the only means of communication, the EU carries out a language policy reevaluating linguistic diversity. According to this policy, linguistic diversity is a symbol and marker of the EU, differentiating (positively) the EU from linguistically homogeneous powers like the USA or

10 This kind of opposition towards English in the European Union is analysed in detail in: S. Wright, Language Policy and Language Planning. From Nationalism to Globalisation, Basingstoke 2004, pp. 26-30. 
China. (Of course, this statement relates to the official languages, as in the private sphere many languages are in use.) Additionally, still according to this reasoning, respecting national languages as principal languages of communication and symbolic languages of $\mathrm{Eu}-$ ropean citizens makes Europeans "feel at home" in their language communities, and treat the European Union not as something alien and hostile but as something familiar and intimate. There are suspicions, however, that the policy of linguistic diversity in the EU has another purpose: to stop the spread of English as the main, if not the only, language of the EU. According to this reasoning, the main promoter of this policy is France. ${ }^{11}$ The policy of linguistic diversity in the EU also has its institutional dimension: the existence of a high functionary (EC commissioner) in charge of multilingualism.

The EU policy of multi-lingualism is highly ambiguous. Its assumption is equality of languages, but in practice it distinguishes between more and less important languages. As mentioned earlier, the EU recognises only national official languages as its official languages ignoring other languages regardless of their official status, number of speakers etc. Promotion or maintenance of linguistic diversity, other than the diversity of official EU languages, has been shifted to other institutions, first of all to the Council of Europe and the European Bureau for Lesser Used Languages (EBLUL) (which stopped functioning a few years ago). These institutions defend languages classified as regional or minority languages ("lesser used") via non-obliging conventions, while ignoring the languages of immigrants and thus distinguishing between "better" and "worse" languages. The fact that the defence of these languages is assigned to other institutions and not to the European Union itself, despite declarations on linguistic diversity, also has a political context. The main opponent to the protection of regional and minority languages by the $\mathrm{EU}$ is France ${ }^{12}$ (together with Greece and some other countries). This attitude confirms the suspicion that the real aim of the policy of linguistic diversity of the EU is defending national languages against the spread of English.

It is worth mentioning that in Europe, especially among minority and ethno-regional communities in the new EU member states, the declared EU idea of linguistic diversity, of defence of regional and minority languages, is understood as a "European norm" and that they can rely on the EU in their efforts to defend their linguistic rights. Quite often they are disappointed when EU rulings state that matters related to language and culture are in the exclusive competence of national governments.

\section{FINAL REMARKS}

As can be seen from the above discussion, the European Union is pursuing a contradictory language policy: on the one hand it promotes linguistic diversity (in practice limited to the official national languages of member states) in the name of equality of member

11 Ibid., p. 126, 127.

12 For instance France refused to ratify the European Charter for Regional or Minority Languages, it opposed incorporation of EBLUL to structures of the EU, etc. 
states and equality of $E U$ citizens and resulting from the nature of the $\mathrm{EU}$ as a free association of equal sovereign states, on the other hand, in the name of the smooth functioning of EU institutions and economic efficiency, it supports some languages more than others. The first kind of policy generates practical problems of implementation (e.g. the problem of translation and interpretation) while the second kind causes political and economic conflicts. It seems that the EU must continue its contradictory language policy because no radical solution (absolute equality of languages or one language for the EU) can be accepted. In such as situation, EU institutions and politicians must continuously find solutions to emerging issues, and European citizens must learn foreign languages.

\section{BIBLIOGRAPHY}

'Eksperci przeciwko jednolitemu patentowi europejskiemu', Gazeta Wyborcza, 14 February 2013. 'The EU's Unitary Patent: Yes, Ja, Oui, No, No', The Economist, 13 December 2012.

Niklewicz K., 'Nasi wygrywają z biurokracją Unii Europejskiej', Gazeta Wyborcza, 22 May 2007. Lammert N., 'Apokalyptische Erfahrungen', Der Spiegel, 2 October 2006.

Łada A., 'Patent na Prezydencję?', Gazeta Wyborcza 8 March 2011.

Łuczak J., Polityka jezykowa Unii Europejskiej, Warszawa 2010.

Maciejewicz P., 'Holandia chce Polaków do pracy. Ale bez zobowiązań', Gazeta Wyborcza, 31 December 2010.

Marácz L., 'Multilingualism in Europe: Policy and Practice Introduction to Part I', European Studies, No. 29 (2012).

'Piechociński nie zwróci się do rządu o przyjęcie jednolitego patentu', Gazeta Wyborcza, 20 March 2013.

Szul R., 'The Linguistic Situation in Europe: between Regionalism and European Integration', The Polish Foreign Affairs Digest, Vol. 4, No. 1 (2004).

Szul R., 'Tożsamość europejska a kwestia językowa w Unii Europejskiej', Studia Regionalne i Lokalne, No. 4 (2007).

Truchot C., Europe. L'enjeu linguistique, Paris 2008 (Études de la Documentation Française, 5280).

“Un brevet unique permettra à l'Union européenne d'être plus compétitive". Entretien avec le professeur Alain Pompidou', Entretien d'Europe, No. 55 (2011), at <http://www.robert-schuman.eu/entretien_europe.php?num=55>.

Wright S., Language Policy and Language Planning. From Nationalism to Globalisation, Basingstoke 2004.

Żylińska J., 'KE broni konsultacji publicznych ws. gazu łupkowego', Gazeta Wyborcza, 19 April 2013.

Dr hab. Roman SZUL, prof. UW - Professor at the University of Warsaw Centre for European Regional and Local Studies. His research interests include theory of nationalism and regionalism, language politics and policy as well as the European integration, and international economic and political relations. 